\title{
Bromebric Acid
}

National Cancer Institute

\section{Source}

National Cancer Institute. Bromebric Acid. NCI Thesaurus. Code C72089.

A derivative of bromoacrylic acid with cytostatic and antineoplastic activity. Bromebric acid appears to inhibit purine synthesis, oxidative phosphorylation and DNA synthesis.

This agent inhibits tumor cell growth and causes cell cycle arrest. This agent may also have some use in the phrophylaxis of migraine. 